3. Лозовецька В. Т. Професійна орієнтація молоді в умовах сучасного ринку праці. К.: ІПТО НАПН України, 2012. 157 с.

4. Ошуркевич Н. Генеза та сутнісний зміст професійного самовизначення особистості. Педагогічний процес: теорія і практика. 2018. Вип. 4. С. 43-49.

5. Семенов И. Н., Савенкова И. А. Рефлексивно-психологические аспекты развития и профессионального самоопределения личности. Мир психологии. 2007. № 2. С. 203-216.

DOI https://doi.org/10.30525/978-9934-588-80-8-1.27

\title{
ПСИХОЛОГО-ПЕДАГОГІЧНІ УМОВИ РОЗВИТКУ ПРОФЕСІЙНОЇ ІДЕНТИЧНОСТІ СТУДЕНТІВ ГУМАНІТАРНИХ ФАКУЛЬТЕТІВ У ЗАКЛАДІ ВИЩОЇ ОСВІТИ
}

\author{
Мисник М. О. \\ студентка 2 курсу магістратури факультету психології \\ Київський національний університет імені Тараса Шевченка \\ м. Київ, Украӥна
}

Сучасною особливістю розвитку психологічної та педагогічної наук у вищій школі $є$ їі підвищений інтерес до розробки стратегій рішень прикладних проблем. Таким чином, звертається особлива увага до дослідження процесу освітньо-професійної соціалізації студентів, формування їх професійно важливих якостей та пізнавальних процесів, пошук критеріїв та показників професійного, особистісного, соціального і розумового розвитку, вияв психолого-педагогічні умов розвитку їх професійної ідентичності тощо.

На цій основі здійснюється пошук традиційних та інноваційних освітніх, тренінгових технологій на різних стадіях професіонального становлення студентів і викладачів як суб'єктів освітнього простору та професійної соціалізації вищої школи.

Варто зазначити, університет як соціокультурна система, не є тільки транслятором професійних знань майбутньому фахівцю у певній галузі, a $\epsilon$ середовищем розвитку його професійної ідентичності на всіх етапах навчання. А також виступає фундаментом для формування важливих психічних утворень, які у єдності забезпечують становлення особистості як професіонала та забезпечують їй особистісне та кар'єрне зростання. Таким чином, майбутні фахівці починають усвідомлювати 
свої професійні можливості, вчаться планувати розвиток власної кар'єри, підвищують свою комунікативну і професійну компетентність, оптимізують власний стиль поведінки та розумової діяльності.

Е. Зеєр та Е. Симанюк підтверджують, що на стадії професійної освіти розчарування в обраній професії переживає багато студентів. Виникає незадоволення окремими предметами, з'являються сумніви у правильності професійного вибору, переживання людиною почуття відсталості від життя, втома, зниження рівня активності і виникнення відчуття вичерпаності своїх можливостей, втрата відчуття нового, внутрішня розгубленість, зниження власної самооцінки і усвідомлення необхідності переоцінки себе. Це ознаки так званої кризи професійного вибору. Як правило, вона чітко проявляється в перший і в останній рік навчання у ЗВО. Завдання вищої школи - допомогти цю кризу подолати, тому питання особистісного розвитку студента і формування його професійної ідентичності $\epsilon$ ключові в теорії та практиці вдосконалення роботи сучасного закладу вищої освіти як інституту освітньої соціалізації. При цьому однією 3 провідних проблем $€$ побудова такої системи освітнього процесу, яка б оптимально враховувала особливості й закономірності не лише особистісного розвитку студента, а й його професійного становлення як спеціаліста та пошук педагогічно доцільних способів розв'язання криз професійного вибору, що безпосередньо впливають на подальшу траєкторію розвитку людини. Конструктивно переживаючи кризу, особистість підіймається на більш високий рівень розвитку, ініціює нові етапи професійного розвитку i самоактуалізації, стає життєво i професійно більш компетентною [3, с. 115, 116-120].

Результати теоретичного аналізу вказують на те, що під час оволодіння студентами обраною спеціальністю у них спочатку виникає уявлення про себе як про фахівця свого напряму взагалі, а згодом, після методологічної й методично-практичної діяльності, 3'являються професійні уявлення про себе як професіонала. Але професіоналізм не зводиться лише до наявності певних знань та умінь у особистості, а суттєво пов'язаний з ії ціннісним ставленням до себе як професіонала, до професійної діяльності як форми самореалізації та до цінностей, що притаманні професійному співтовариству. При цьому на різних етапах оволодіння спеціальністю професійна ідентичність може якісно відрізнятися, а особистість здатна ставити під сумнів цінності та правила професійного співтовариства, які ще нещодавно здавалися їй беззаперечними [1, с. 17-18].

Таким чином, завданням закладу вищої освіти $є$ розвиток професійної ідентичності студента, шляхом створення умов захищеності, 106 
вірою в свої реальні та потенційні можливості, гордістю за свою професію, розумінням іiі важливості та потрібності, задоволеності собою $\mathrm{i}$ результатами своєї праці, перспективами свого росту й умовами своєї праці [5, с. 192].

Професійну ідентичність можна розвивати та підтримувати завдяки інфраструктурі, яка сприяє створенню почуття спільності серед учасників освітнього простору. Також умовою розвитку професійної ідентичності у закладі вищої освіти може бути розвиток консультативної служби 3 питань кар'єри, що надає психологічну підтримку молодого фахівця на всіх етапах навчання. Вагомою умовою, що сприяє розвитку професійної ідентичності студента, $є$ створення умов закладом вищої освіти для продовження та підвищення кваліфікації, орієнтація на концепцію безперервної освіти. Не менш важливим $\epsilon$ те, що кожен студент за час навчання у закладі вищої освіти має зрозуміти, що він несе відповідальність за свій професійний вибір та розуміти, що інвестування в себе і свій розвиток $€$ джерелом професіоналізму [6, с. 15].

Дослідження професійної ідентичності дозволяє дослідити існуючі взаємозв'язки між цінностями та досвідом людини у професійному становленні, а також між переконаннями, поглядами, мотивами та досвідом, завдяки яким люди визначають себе у своєму поточному або передбачуваному професійному житті.

Важливою психолого-педагогічною умовою розвитку професійної ідентичності $\epsilon$ сприятливий психологічний клімат закладу освіти, факультету, кафедри, де навчається студент. В сучасних умовах для його оптимізації використовуються різноманітні інформаційно-комунікативні технології.

Педагогічний досвід викладачів кафедри педагогіки КНУ імені Тараса Шевченка, дозволяє стверджувати про важливість використання новітніх технологій щодо розвитку професійної ідентичності. Це технології коучингу, менторінгу, медіації, модерації та фасилітації в освітньому процесі вищої школи [2, с. 36]. Наприклад, у взаємозв'язку 3 визначенням і філософією технології коучингу, Міжнародна федерація коучингу дає наступне визначення професійного коучингу як технології розвитку професійної ідентичності фахівців: «професійний коучинг - це процес, що допомагає людині досягти якісно нових результатів у своєму особистому і професійному житті». В процесі це дозволяє поглибити свої пізнання, поліпшити ефективність професійної діяльності та підвищити якість життя. Коучинг прискорює процес просування людини до мети, допомагаючи зосередитися на бажаному результаті і відкриваючи ширший вибір альтернатив [4]. 
Технологія коучингу створює важливі психолого-педагогічні умови у процесі розвитку професійної ідентичності студентів гуманітарних факультетів. Зокрема, створення умов тренінгової роботи, умов практичної діяльності щодо постановки професійних цілей і перетворення їх у задачі, цілепокладання у побудові професійної кар'єри, розвитку самосвідомості, побудова поля особистісної стратегії розвитку. Також важливою психолого-педагогічною умовою є позитивний партнерський психологічний клімат середовища освітнього простору та ефективної комунікації [2, с. 33].

Отже, розвиток професійної ідентичності студентів гуманітарних факультетів залежить від багатьох умов у процесі навчання. Зокрема, використання сучасних технологій роботи щодо розвитку професійної ідентичності і трансформація їх в умовах освітнього процесу ЗВО у сучасних умовах є перспективою подальших досліджень.

\section{Література:}

1. Иванова Н. Л. Профессиональная идентичность студентов магистрантов: проблемы формирования // Психология обучения. - 2015. № 12. - С. 16-28.

2. Кошечко Н. Інноваційні освітні технології навчання та викладання у вищій школі / Н. Кошечко // Вістник Київського національного університету імені Тараса Шевченка. Педагогіка. - 2015. - Вип. 1. C. 35-38. - Режим доступу: http://nbuv.gov.ua/UJRN/vknutshp_ 2015_1_10

3. Психологія вищої школи / О. І. Власова, В. А. Семиченко, С. Ю. Пащенко, Я. Г. Невідома / за ред. О. І. Власової : підручник. - К. : ВПЦ «Київський університет», 2014. - 470 с.

4. Международная федерация коучинга // [Электронный ресурс]. Режим доступа: https://erickson.ru/coaching/icf.php

5. Черненко В. П., Кравченко К. В., Професійна ідентичність студентів старших курсів «Наука і освіта», № 2-3, 2016. С. 191-195.

6. Caza B. B., \& Creary S. J. (2016). The construction of professional identity [Electronic version]. Retrieved [insert date], from Cornell University, SHA School site: http://scholarship.sha.cornell.edu/articles/878 